\title{
Analisis Perbandingan Performansi Protokol Ad Hoc On- Demand Distance Vector dan Zone Routing Protocol Pada Mobile Ad Hoc Network
}

\author{
Bayu Satria Kusuma ${ }^{* 1}$, Diah Risqiwati ${ }^{2}$, Denar Regata Akbi ${ }^{3}$ \\ 1,2,3 Universitas Muhammadiyah Malang \\ bayusatriakusuma@gmail.com¹, diah.rizqiwati@gmail.com², dregata.dosen@gmail.com³
}

\begin{abstract}
Abstrak
Jaringan Ad Hoc adalah jaringan wireless dengan beberapa Mobile node yang tidak memiliki router tetap. Setiap node ini dapat berfungsi sebagai router yang dapat mencari dan menangani jalur ke node yang lain dalam suatu jaringan. Setiap node pada jaringan bersifat Mobile sehingga topologi dari jaringannya selalu berubah-ubah. AODV dan ZRP merupakan contoh routing protocol yang efisien untuk jaringan Ad Hoc pada tipe routing protocol masingmasing. AODV untuk tipe routing protocol reactive dan ZRP untuk tipe routing protocol hybrid. Setiap routing protocol tentu akan memiliki kemampuan yang berbeda dalam kecepatan mencari jalur routing dan kemampuan pengiriman jumlah packet dalam jaringan, sehingga Quality of Service (QoS) untuk setiap routing protocol juga berbeda. Oleh karena itu, menjadi penting untuk mengetahui kecepatan dan efisiensi routing protocol dalam menentukan routing yang akan digunakan dalam studi kasus. Dalam Penelitian melakukan analisis QoS jaringan ad hoc pada routing protocol AODV dan ZRP dengan parameter yang di uji adalah End to End Delay, Jitter, Packet Delivery Ratio dan Throughput. Setelah data terkumpul, dilakukan analisa dengan melihat QoS setiap protocol routing. Hasil pengujian memperlihatkan bahwa masing-masing routing protocol yang diteliti, routing protocol AODV memiliki waktu yang lebih cepat dalam proses pengiriman packet ke node selanjutnya dengan nilai rata-rata 0.3134 detik dari pada routing protocol ZRP yang memiliki nilai 0.3891 detik. Untuk jumlah packet yang terkirim routing protocol $Z R P$ lebih baik dengan rata-rata throughput $963.34 \mathrm{~Kb}$ dibandingkan dengan routing protocol AODV.
\end{abstract}

Kata Kunci: Ad hoc, Ad hoc On-demand Distance Vector, Zone Routing Protocol, Routing Protocol, Quality of Service

\begin{abstract}
Ad Hoc network is a wireless network with a couple of Mobile nodes that do not have a fixed router. Each node can function as a router which can find and handle paths to other nodes in a network. Each node on the network are Mobile so that the topology of the network is always changing. AODV and ZRP is an example of an efficient routing protocol for Ad Hoc network on the type of each routing protocol. AODV is reactive routing protocol and ZRP is for hybrid routing protocol. Each routing protocol will certainly have different capacities to search routing paths in the network and traffic delivery number in the packet network, so the Quality of Service (QoS) for each routing protocol always different. Therefore, it becomes important to know the speed and efficiency routing protocol to determine the routing path. This study was to analyze initialization QoS on the ad hoc network routing protocol AODV and ZRP with the parameters is the End to End Delay, Jitter, Packet Delivery Ratio and Throughput. After the data were collected, we do some analyzed by look at the QoS each routing protocol routing. The test results show us that each routing protocol inspected, $A O D V$ routing protocol has a faster time in the process of sending the packet to the next node with average score 0.3134 second than routing protocol ZRP. For a number of packets sent ZRP routing protocol have an average score $963.34 \mathrm{~Kb}$ is better than $A O D V$ routing protocol.
\end{abstract}

Keywords: Ad hoc, Ad hoc On-demand Distance Vector, ZRP, Routing Protocol, Quality of Service 


\section{Pendahuluan}

Kebutuhan manusia untuk melakukan komunikasi semakin besar dari waktu ke waktu. Saat ini, komunikasi bergerak menjadi kebutuhan komunikasi yang sudah tidak terpisahkan lagi bagi manusia. Begitu juga halnya dengan kebutuhan komunikasi untuk daerah-daerah yang belum dijangkau oleh infrastruktur tetap. Kehadiran Mobile Ad hoc Network (MANET) menjadi jawaban untuk komunikasi yang belum mempunyai infrastruktur yang tetap. MANET adalah sebuah jaringan yang terdiri dari beberapa node-node yang bersifat Mobile, dimana node-node Mobile tersebut dapat berkomunikasi dengan tanpa menggunakan jalur komunikasi permanen, atau bersifat sementara (ad hoc) [1].

Fungsi dari jaringan MANET sangat tergantung routing protocol menentukan rute diantara node. Routing adalah proses pemilihan jalan pada jaringan yang digunakan untuk mengirimkan paket data ke node tujuan. Routing protocol berbeda dengan routing. Routing protocol adalah standarisasi yang melakukan kontrol terhadap arah pergerakan node dalam meneruskan paket diantara perangkat komputasi dalam MANET, dimana routing protocol berfungsi untuk mencarikan jalur rute terbaik dari jalur yang di lalui melalui mekanisme pembentukan tabel routing [2].

Mekanisme protocol routing yang ada di MANET umumnya dikategorikan menjadi 3 jenis, yaitu proactive, reactive, dan hybrid. Protocol proactive bertugas untuk memperbarui tabel routing secara berkala, sedangkan protocol reactive berfungsi untuk membentuk rute jika suatu node meminta untuk dibuatkan rute pengiriman pesan, hybrid routing protocol ini adalah jenis protocol yang mempertimbangkan keuntungan dari jenis lainnya, yaitu reactive routing protocol dan proactive routing protocol. Zone Routing Protocol (ZRP) menggabungkan kedua jenis protocol tersebut dengan menggunakan Intrazone Routing Protocol (IARP) sebagai bagian dari proactive routing protocol dan Interzone Routing Protocol (IERP) sebagai bagian dari reactive routing protocol. Sedangkan tanggung jawab untuk pengiriman request routing, ZRP menggunakan Broadcast Resolution Protocol (BRP).

Routing protocol reactive juga memiliki beberapa protocol yang dapat digunakan dalam MANET, sebagai contoh Ad Hoc On-Demand Distance Vector (AODV), Dynamic Source Routing (DSR), dan Associatively-Based Routing (ABR). Dalam hal ini AODV merupakan protocol routing yang bersifat reactive. Protocol ini bersifat reactive, karena protocol ini mulai bekerja saat ada permintaan dari source node untuk mencari jalur-jalur yang digunakan untuk mengirimkan pesan ke node tujuan. AODV berusaha untuk menemukan jalur yang tidak ada loop dan menemukan jalur terpendek untuk menuju node tujuan [3].

Pada penelitian ini, penulis melakukan perbandingan kinerja performansi dari routing protocol AODV dan ZRP yang bertujuan untuk mengetahui kelemahan dan kelebihan dari masing-masing protocol jika diterapkan pada jaringan MANET, sehingga diharapkan dapat dijadikan acuan untuk melakukan pemilihan protocol routing terbaik pada jaringan MANET.

\section{Metode Penelitian}

\subsection{Jaringan Ad Hoc}

Jaringan wireless yang terdiri dari kumpulan mobile node (mobile station) yang bersifat dinamik dan spontan, dapat diaplikasikan dimana pun tanpa menggunakan bantuan jaringan infrastruktur (Access Point) yang telah ada. Pada jaringan ad-hoc sendiri terbagi menjadi 7 jenis jaringan [2], yaitu:

1. WANET (Wireless Ad Hoc Network)

2. MANET (Mobile Ad Hoc Network)

3. VANET (Vehicular Ad Hoc Network)

4. SPANs (Smartphone Ad Hoc Network)

5. iMANETs (Internet Based Mobile Ad Hoc Netwok)

6. Military / Tactical MANETs

7. SPAN (Self Powered Ad Hoc Network).

\subsection{Jaringan MANET (Mobile Ad Hoc Network)}

MANET adalah sebuah jaringan yang terdiri dari beberapa node yang bersifat mobile, dimana node-node mobile tersebut dapat berkomunikasi dengan tanpa menggunakan jalur komunikasi yang permanen, atau bersifat sementara (ad hoc) [1]. Node-node dalam jaringan ini berfungsi juga sebagai router yang bertanggung jawab untuk mencari dan menangani rute ke 
setiap node dalam jaringan. MANET yang ingin interkoneksi dengan fixed host harus melewati gateway terlebih dahulu.

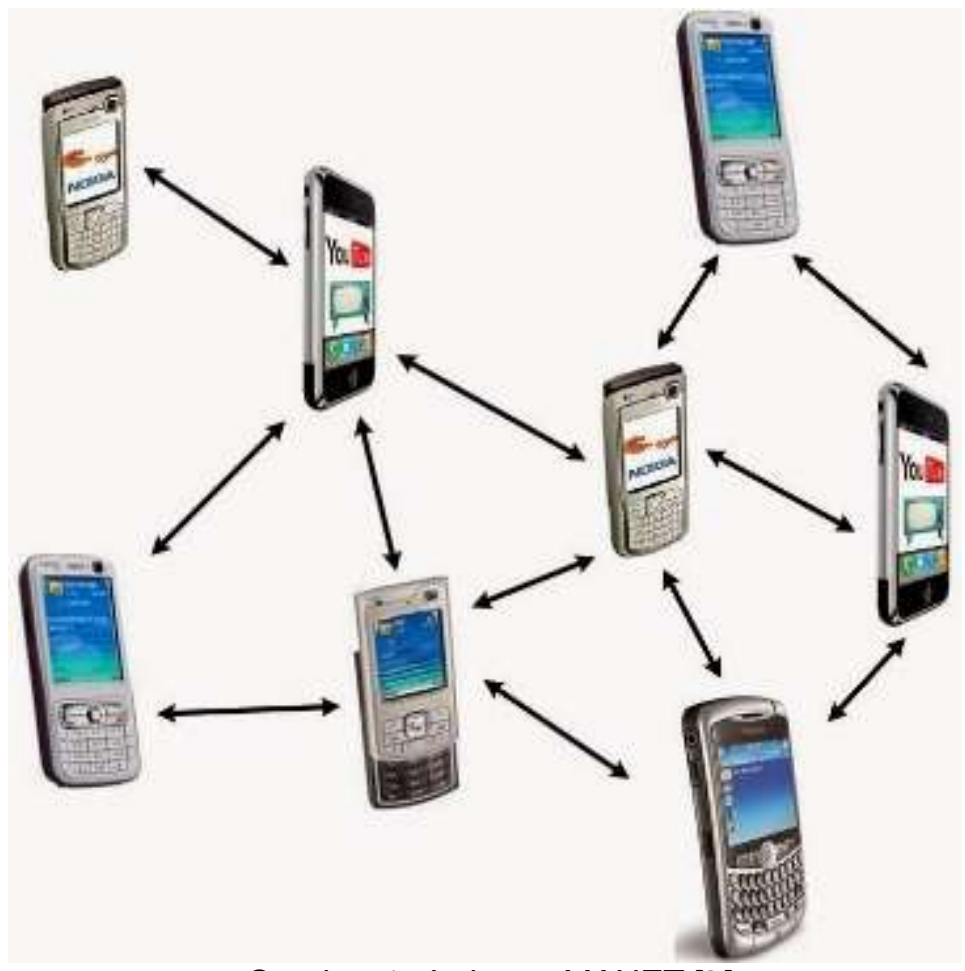

Gambar 1. Jaringan MANET [2]

Pada Gambar 1, MANET bebas terhubung ke segala arah atau bergerak secara independen (bebas), maka dari itu penerusan ke perangkat lain sering berubah dan meneruskan ke lalu lintas jaringan yang tidak terkait.

\subsection{Protocol MANET}

Mekanisme protocol routing yang ada di MANET umumnya dikategorikan menjadi 3 jenis, yaitu proactive, reactive dan hybrid [4], antara lain:

\subsubsection{Proactive Routing}

Algoritma proactive mengelola tujuan pengiriman paket dan rute yang dilewati dengan cara mendistribusikan routing tabel ke seluruh jaringan. Hal ini dapat memperlambat aliran data jika terjadi restrukturisasi routing tabel karena harus mengulang proses tersebut dari awal lagi.

\subsubsection{Reactive Routing}

Algoritma reactive mencari rute (on demand) dengan cara membanjiri jaringan dengan paket router request. Sehingga dapat menyebabkan jaringan penuh (clogging).

\subsubsection{Hybrid Routing}

Tipe protocol ini menggabungkan antara proactive routing dengan reactive routing. Sehingga jenis routing ini dapat berperan sesuai dengan kebutuhan saat terjadi pengiriman paket.

\subsection{Protocol AODV}

AODV merupakan protocol routing yang bersifat reaktif. Protoco/ ini bersifat reaktif karena protocol ini mulai bekerja saat ada permintaan dari source node untuk mencari tahu jalur-jalur yang digunakan untuk mengirimkan pesan ke node tujuan. AODV berusaha untuk menemukan jalur yang tidak ada loop dan menemukan jalur terpendek untuk menuju node tujuan [1].

Seperti yang telah dijelaskan sebelumnya, AODV bekerja ketika ada permintaan dari source node untuk menemukan rute menuju destination node karena ada pengiriman pesan. Untuk menemukan jalur yang terbaik bagi source node, maka AODV melakukan route discovery dengan menyebarkan route request (RREQ) ke semua node yang bersebelahan dengan source 
node. Node tetangga tersebut mengirimkan RREQ ke node tetangganya lagi hingga berakhir di node tujuan. Setelah RREQ sampai ke node tujuan, maka node tujuan membalas pesan RREQ dengan route reply (RREP). Jalur yang dipilih tentunya rute dengan jarak terpendek dan cost yang lebih rendah dibandingkan dengan jalur lainnya, seperti tergambar pada Gambar 2.

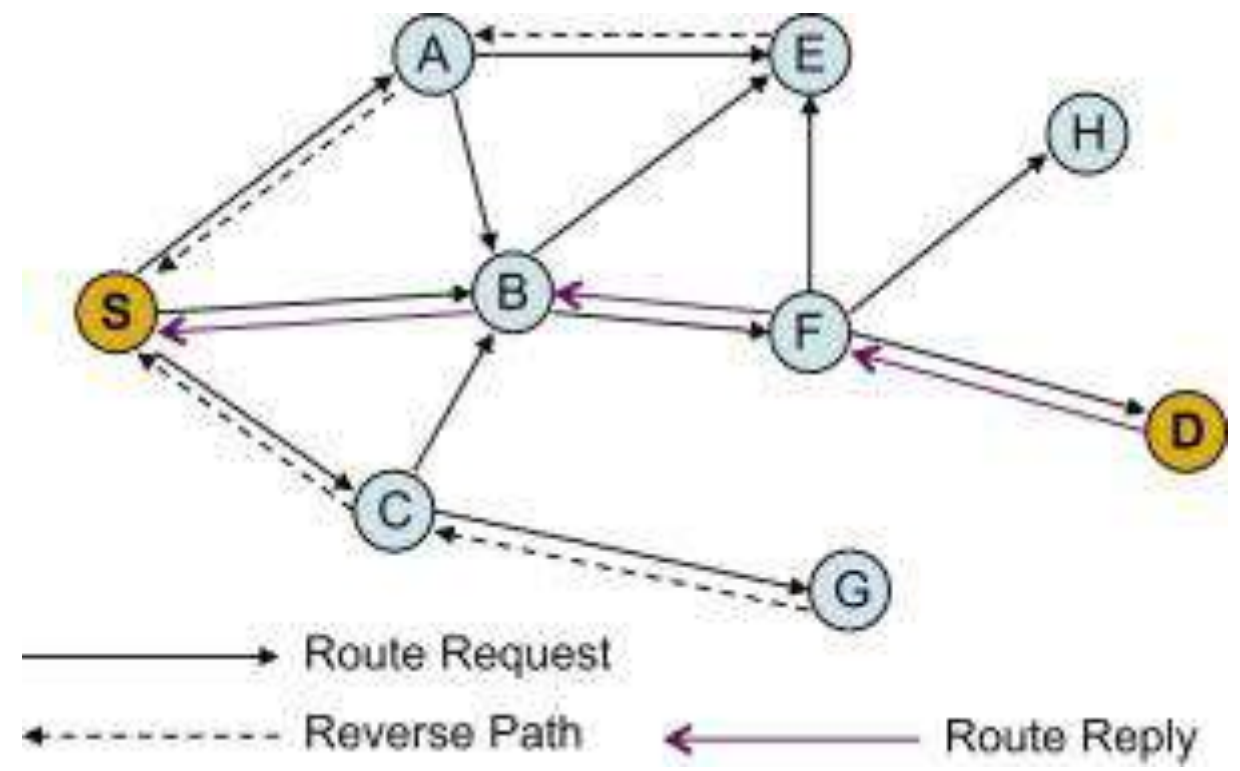

Gambar 2. Proses Route Discovery Pada AODV [1]

\subsection{Protocol ZRP}

Zone routing protocol (ZRP) adalah salah satu dari contoh hybrid routing protocol dan pengertian hybrid routing protocol sendiri adalah kombinasi dari kedua tipe protocol routing, proactive routing protocol dan reactive routing protocol [5] [6].

Pada Gambar 3, ZRP terdiri dari dua prosedur, intra-zone routing protocol (IARP) dan inter-zone routing protocol (IERP). IARP digunakan di dalam zone routing [7], dan IERP digunakan saat jarak antara sumber (source) serta tujuan (destination) lebih lebar daripada radius zone routing [7]. Setiap device harus menjaga informasi routing dari seluruh device di dalam zona routing, dan memperbarui informasi ketika topologi berubah. Ketika jarak menuju destination lebih pendek daripada zona radius, destination dapat ditemukan oleh IARP berdasarkan informasi routing pada setiap device. Akan tetapi, jika destination berada diluar zona, IERP bergantung pada broadcasting sebuah route request untuk mencari atau menemukan destination. Untuk permintaan rute yang berada diluar area network, mekanisme kontrol permintaan dilakukan oleh BRP [8]. Setiap device yang menerima route request selalu mengulangi prosedur yang sama sampai destination ditemukan.

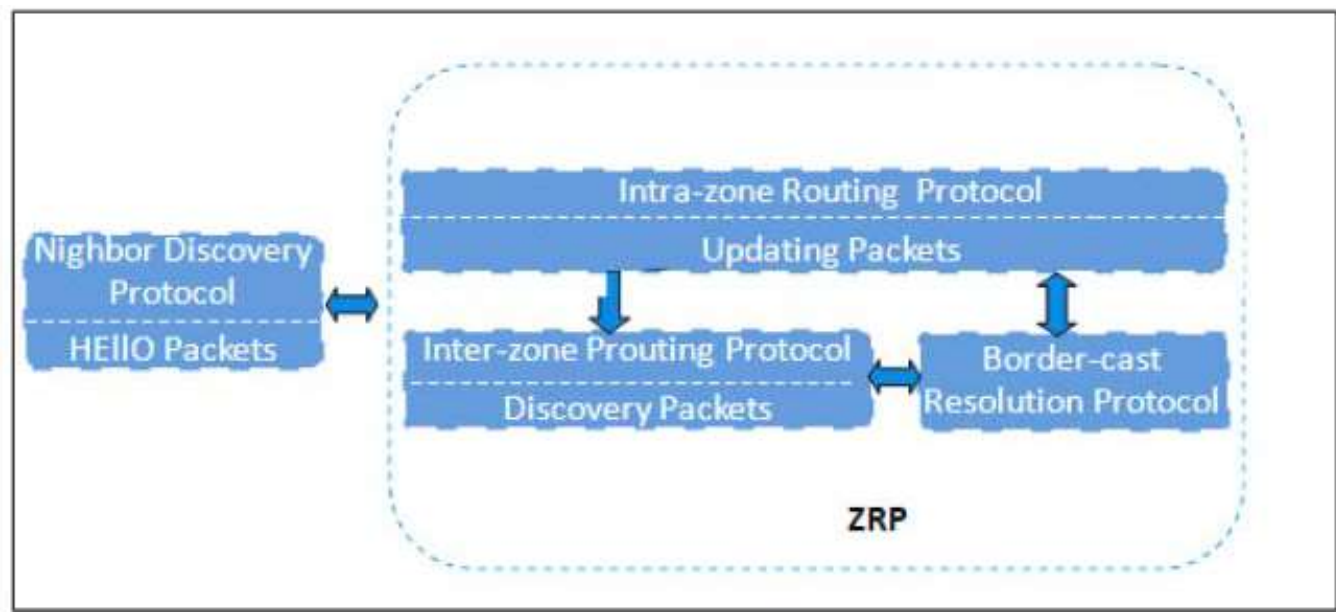

Gambar 3. Arsitektur Zone Routing Protocol (ZRP) [9]

KINETIK Vol. 2, No. 3, Agustus 2017: 165-174 


\subsection{Quality of Service}

Quality of service (QoS) dari sebuah jaringan adalah kemampuan dalam sebuah jaringan tersebut untuk menyediakan layanan terhadap lalu lintas data jaringan tersebut. QoS pada jaringan ad hoc menjadi penting karena kelebihan yang dimiliki oleh jaringan wireless ad hoc, yaitu node-node yang ada dapat bertambah dan berpindah pada akhirnya berpengaruh terhadap jarak antar node dan trafik jaringan kualitas layanan network terhadap mobilisasi data di dalamnya. Dengan adanya QoS pada jaringan mobile ad hoc, diharapkan jaringan dapat memberikan layanan yang lebih baik dan terencana. Penilaian QoS meliputi throughput, end to end delay, jitter, dan packet delivery ratio.

\subsection{Network Simulator-2}

Network simulator-2 adalah perangkat lunak untuk kebutuhan simulasi aplikasi, protocol, tipe jaringan, elemen-elemen jaringan, pemodelan jaringan, dan pemodelan lalu-lintas jaringan. network simulator-2 menggunakan dua buah bahasa pemrograman standar, yaitu simulator berorientasi obyek yang ditulis dalam $\mathrm{C}++$ dan OTcl (object oriented extension of $\mathrm{Tcl}$ ) untuk eksekusi terhadap perintah-perintah yang ditulis sebagai script dari NS-2.

\subsection{Perl}

Perl adalah bahasa yang bersifat open source untuk berbagai platform system operasi seperti: Unix/Linux, MVS, VMS, Ms DOS/Windows, Macintosh, OS/2, Amiga, dsb [10]. Bersifat open source artinya tersedia secara bebas, jadi tidak perlu takut masalah pembajakan software seperti ketika Anda menggunakan produk Microsoft.

\section{Hasil Penelitian dan Pembahasan}

\subsection{Analisa Sistem}

Berdasarkan perancangan yang telah dibahas pada bagian sebelumnya, simulasi yang dibangun pada penelitian tugas akhir ini menggunakan network simulator-2 yang nantinya digunakan untuk membuat simulasi topologi jaringan yang diuji.

\subsection{Analisa Masalah}

Dengan memilih routing protocol AODV dan ZRP dari begitu banyaknya jenis routing protocol yang ada, maka dapat mempermudah masyarakat memilih jenis routing protocol mana yang digunakan. AODV dan ZRP dipilih karena kedua jenis routing protocol tersebut berbeda, dimana AODV merupakan reactive routing dan ZRP hybrid routing. Kedua routing tersebut mempunyai karakteristik berbeda.

\subsection{Analisa Kebutuhan Sistem}

Beberapa software dan spesifikasi hardware yang dibutuhkan untuk dapat membangun simulasi yang sesuai dengan fungsi dan kebutuhan yang telah dirancang, diantaranya:

1. Software

Perangkat lunak yang dibutuhkan adalah sebagai berikut:

network simulator-2: perangkat lunak untuk kebutuhan simulasi aplikasi, protocol, tipe jaringan, elemen-elemen jaringan, pemodelan jaringan dan pemodelan lalu-lintas jaringan. Pembuatan simulasi sendiri menggunakan gabungan Bahasa antara $\mathrm{C}_{++}$dan Tcl.

2. Hardware

Adapun perangkat keras yang dibutuhkan diantaranya:

Personal Computer (PC)

Spesifikasi dari PC yang digunakan untuk melakukan simulasi jaringan ini, penulis menggunakan laptop dengan spesifikasi sebagai berikut:

1. Processor: Intel Core-i5

2. RAM: $8 \mathrm{~Gb}$

3. Storage: $20 \mathrm{~Gb}$ (untuk menjalankan virtual Ubuntu)

4. Graphic: NVidia Gforce $720 \mathrm{M}$

\subsection{Perancangan Simulasi Jaringan}

Simulasi dilakukan dengan posisi node yang tidak beraturan atau acak. Node yang dibuat adalah dengan menggunakan jaringan wireless. Node juga bergerak secara acak, tidak terpacu dalam kondisi tertentu. Paket yang dikirim dari satu node ke node yang lainnya ditentukan dalam

Analisis Perbandingan Performansi Protokol Ad Hoc On-Demand Distance Vector dan Zone Routing Protocol..., Bayu Satria Kusuma, Diah Risqiwati, Denar Regata Akbi 
skenario yang sudah dibuat sesuai dengan kebutuhan. Selama proses pengiriman paket terjadi hasil dicatat setiap aktivitas QoS (Quality of Service) ke dalam file log yang berformat *tr. Setelah proses pengiriman paket selesai maka dilakukan analisa terhadap file log tersebut agar dapat diketahui QoS pada masing-masing protocol.

\subsection{Parameter Simulasi}

Dalam simulasi jaringan yang dilakukan penulis terdapat 2 parameter yang menjadi acuan, parameter pertama membahas tentang gambaran umum dari simulasi yang digunakan dan parameter kedua membahas tentang gambaran node yang digunakan dalam simulasi tersebut.

\subsubsection{Parameter Simulasi Jaringan}

Alur simulasi yang digunakan untuk analisis QoS jaringan pada routing protocol AODV dan ZRP adalah dengan membuat pola posisi yang sama antara routing protocol AODV dan ZRP. Dengan begitu bisa dibandingkan antara routing protocol AODV dan ZRP. Beberapa asumsi digunakan dalam merancang simulasi, tertera di Tabel 1.

Tabel 1. Parameter Simulasi yang Diujikan

\begin{tabular}{ll}
\hline \multicolumn{1}{c}{ Kriteria } & Keterangan \\
\hline Luas Area & $1000 \mathrm{~m} \times 1000 \mathrm{~m}$ \\
\hline Jumlah Node & 25 node \\
\hline Node Awal & 5 node \\
\hline Jumlah Node & $5,10,15,20,25$ \\
\hline Waktu Simulasi & 10 detik \\
\hline Routing Protokol & AODV dan ZRP \\
\hline Parameter QoS & Jitter, Packet Delivery Ratio, Delay, Throughput \\
\hline
\end{tabular}

\subsubsection{Parameter Node}

Dalam penelitian ini, metode yang digunakan adalah simulasi dengan menggunakan network simulator-2.33. Pada Tabel 2 menjelaskan kecepatan dan pergerakan node sudah ditentukan sehingga node dapat bergerak sesuai dengan skenario. Model ini dapat membuat node memilih tujuan yang sudah ditetapkan. Ketika sebuah node mencapai posisi tujuannya, node tersebut berhenti selama waktu yang sudah ditentukan.

Tabel 2. Parameter Setiap Node

\begin{tabular}{cc}
\hline Parameter & Nilai \\
\hline Tipe Kanal & Wireless Channel \\
\hline Model Propagasi & Two Ray Groung \\
\hline Tipe Network Interface & Wireless \\
\hline Tipe MAC & IEEE 802.11 \\
\hline Maksimal Paket dalam Antrean & 50 \\
\hline Tipe Antrean & Drop Tail \\
\hline Waktu Simulasi & 10 detik \\
\hline Jenis Paket & CBR \\
\hline Routing protocol & AODV/ZRP \\
\hline Model Pergerakan Node & Random Way Point \\
\hline Kecepatan Maksimal & $10 \mathrm{~m} / \mathrm{s}$ \\
\hline
\end{tabular}

\subsection{Topologi Jaringan}

Topologi jaringan dari jaringan MANET pada routing protocol AODV, ZRP dibuat menjadi beberapa kondisi sebagai berikut:

1. Posisi node ditentukan dan posisi node dibuat semirip mungkin antara AODV dan ZRP.

2. Pergerakan posisi node dibuat secara random.

\subsection{Flowchart}

Flowchart dari simulasi yang dilakukan pada jaringan MANET dengan menggunakan routing protocol AODV dan ZRP seperti Gambar 4. 


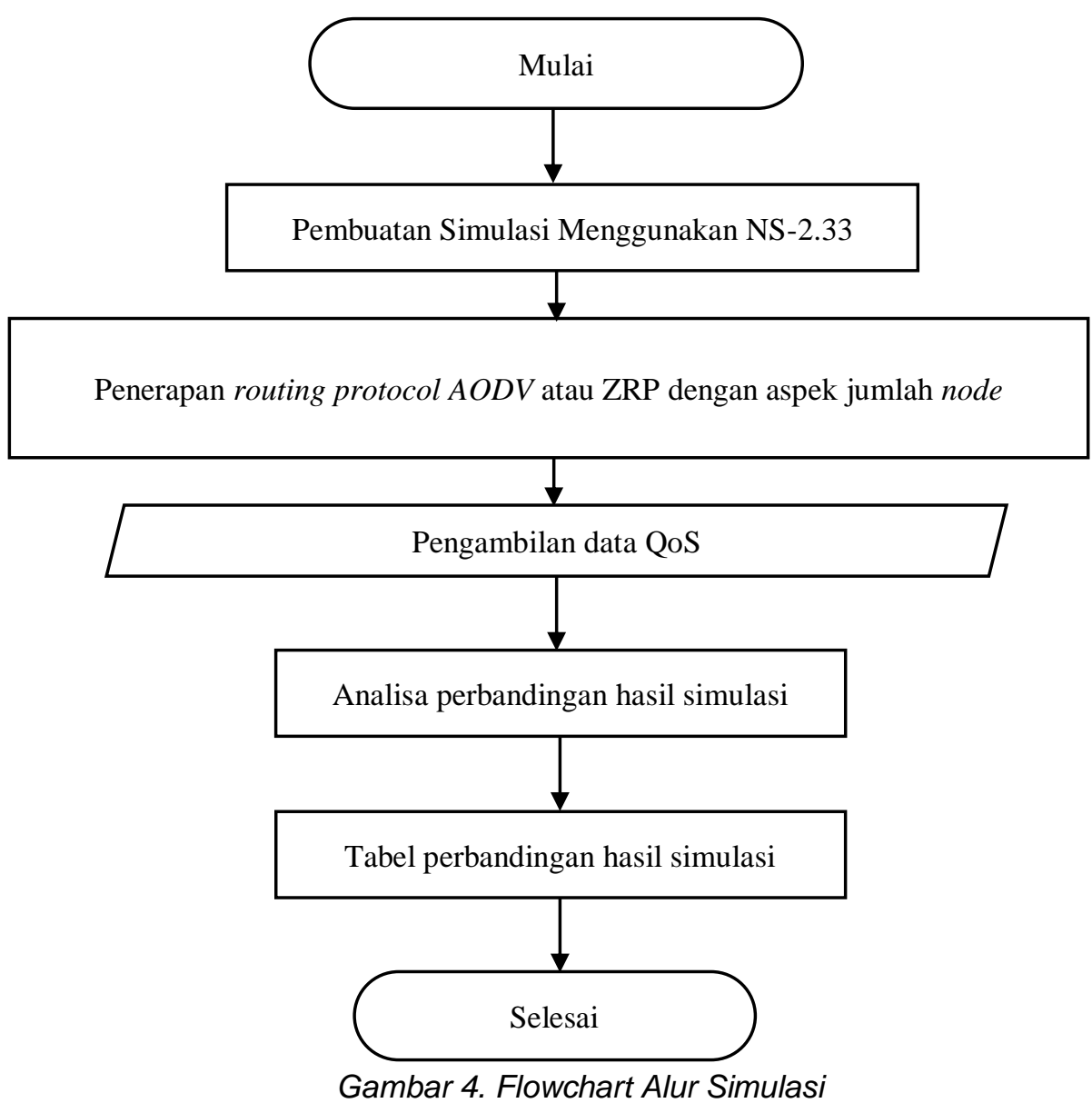

4. Implementasi

\subsection{Implementasi Simulasi}

Untuk membandingkan performansi dari QoS pada routing protocol AODV dan ZRP maka dilakukan tahap skenario perencanaan simulasi jaringan dengan parameter yang telah ditentukan. Topologi dibuat sesuai dengan skenario yang sudah dibuat dari posisi awal node tersebut. Untuk mendapatkan data yang diperlukan, digunakan program tcl script untuk mendapatkan trace file yang dihasilkan oleh NS-2.

Setelah simulasi selesai dijalankan maka menghasilkan beberapa output file dalam ekstensi file yang berbeda-beda seperti .tr dan .nam. Output file dari simulasi yang dibutuhkan untuk kepentingan analisis ini adalah output file dengan extensi file.tr. Output file ini merekam setiap pertukaran data yang terjadi yang dilakukan oleh setiap node selama simulasi berjalan. Berdasarkan data yang ada pada output file inilah penulis menganalisis aliran paket AODV, ZRP pada setiap node asal dan node tujuan paket AODV, ZRP.

\subsection{Pengambilan Data}

Pengambilan data dilakukan sesuai dengan skenario perencanaan simulasi yang telah ditentukan dengan menggunakan script tcl. Dalam penelitian ini alur pengujian ini dimulai dengan penentuan posisi node awal, penempatan node dibuat semirip mungkin antara protocol AODV dan ZRP, kemudian node ditambahkan sebanyak 5 node setiap simulasi. Dari percobaan yang dilakukan menghasilkan data sebanyak 10 data dan ditampilkan dalam bentuk sebuah tabel dan grafik.

\subsection{Simulasi Jaringan}

Pada Gambar 5 menjelaskan proses awal untuk membuat sebuah node dalam sebuah simulasi yang dijalankan. Dalam potongan script diatas menjelaskan mulai dari tipe kanal yang 
digunakan, jaringan berupa jaringan wireless, hingga lama sebuah proses simulasi berakhir. Potongan script diatas adalah jenis routing protocol AODV.

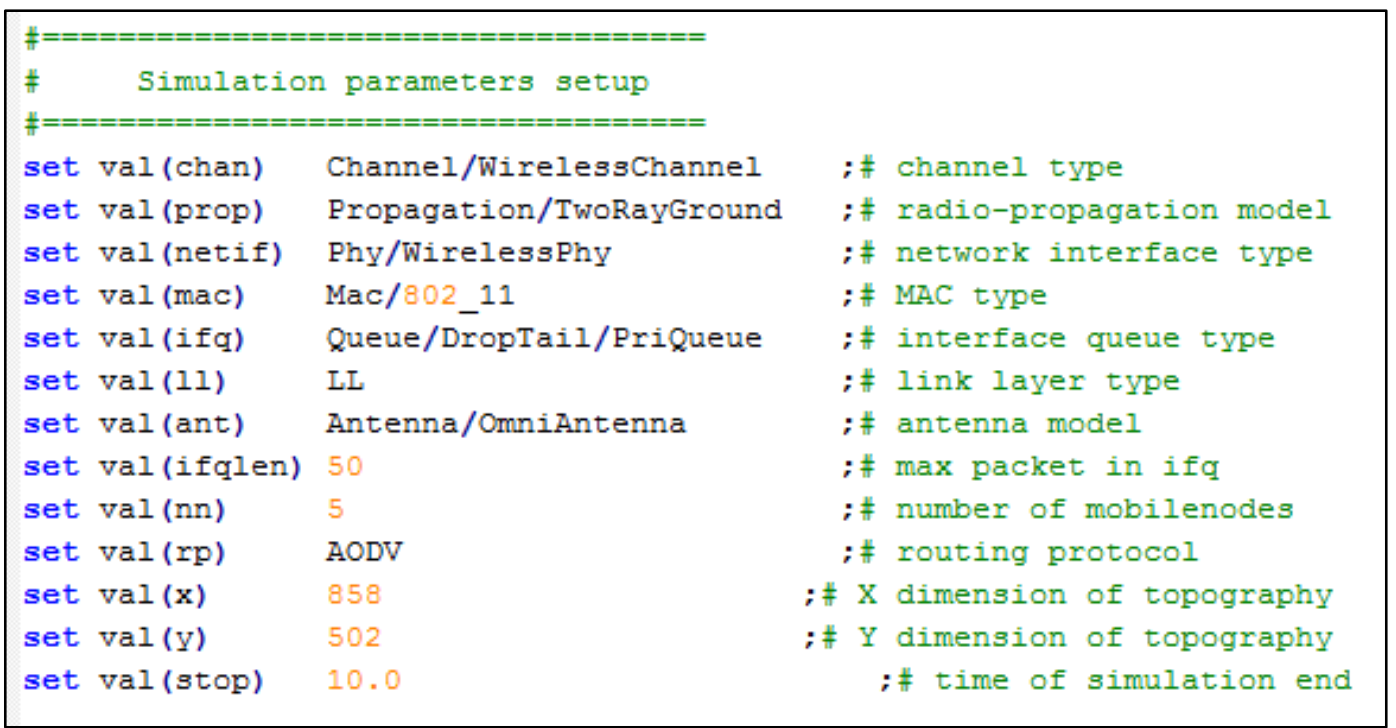

Gambar 5. Parameter Node

Pada Gambar 6 menunjukkan posisi awal dari setiap node pada routing protocol AODV yang diujikan dengan jumlah node 5. Gambar diatas dijalankan dengan NS-2.33 menggunakan perintah "\#ns node-5.tcl"

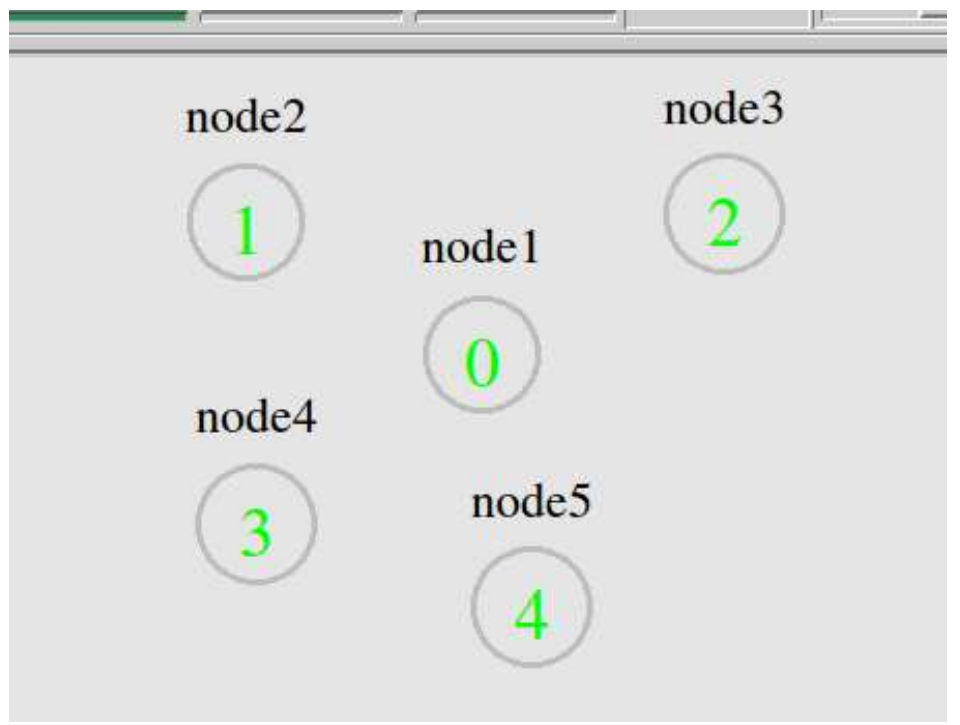

Gambar 6. Topologi AODV 5 Node

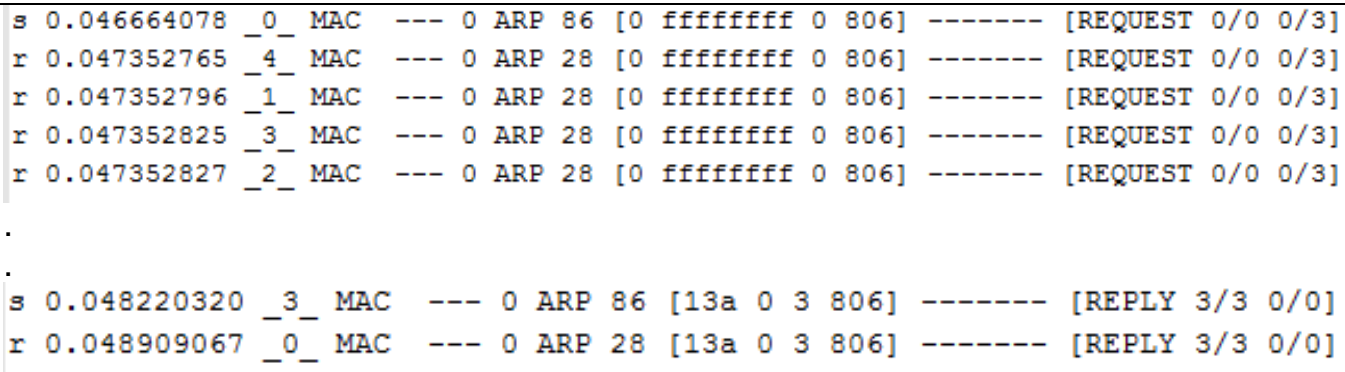

Gambar 7. File Trace Penemuan Jalur 
Proses Gambar 7 merupakan proses penemuan jalur, atau proses pembentukan tabel routing. Proses dimulai dengan proses broadcasting ke node-node terdekat dari node sumber, kemudian mulai membentuk tabel routing sesuai dengan protokol yang digunakan.

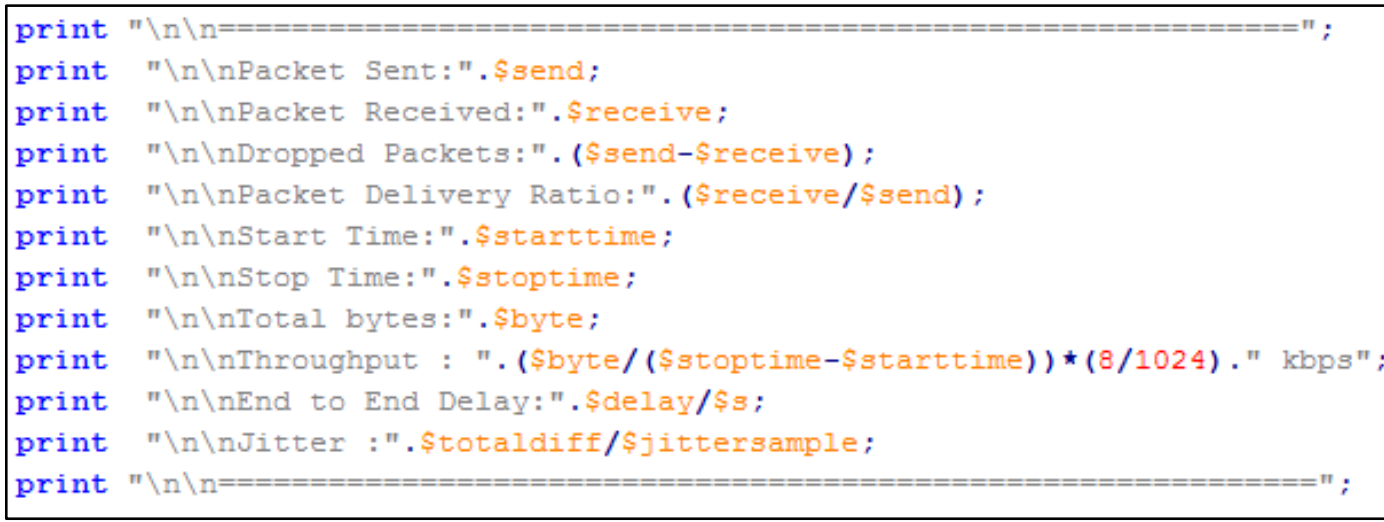

Gambar 8. File all.pl

Pada Gambar 8 adalah potongan script untuk menjalankan fungsi perl agar dapat mengetahui QoS dari masing-masing routing protocol yang diujikan. Dengan menjalankan perintah "perl all.pl out-5.tr" pada terminal Ubuntu maka hasil dari QoS ditampilkan seperti pada Gambar 9.

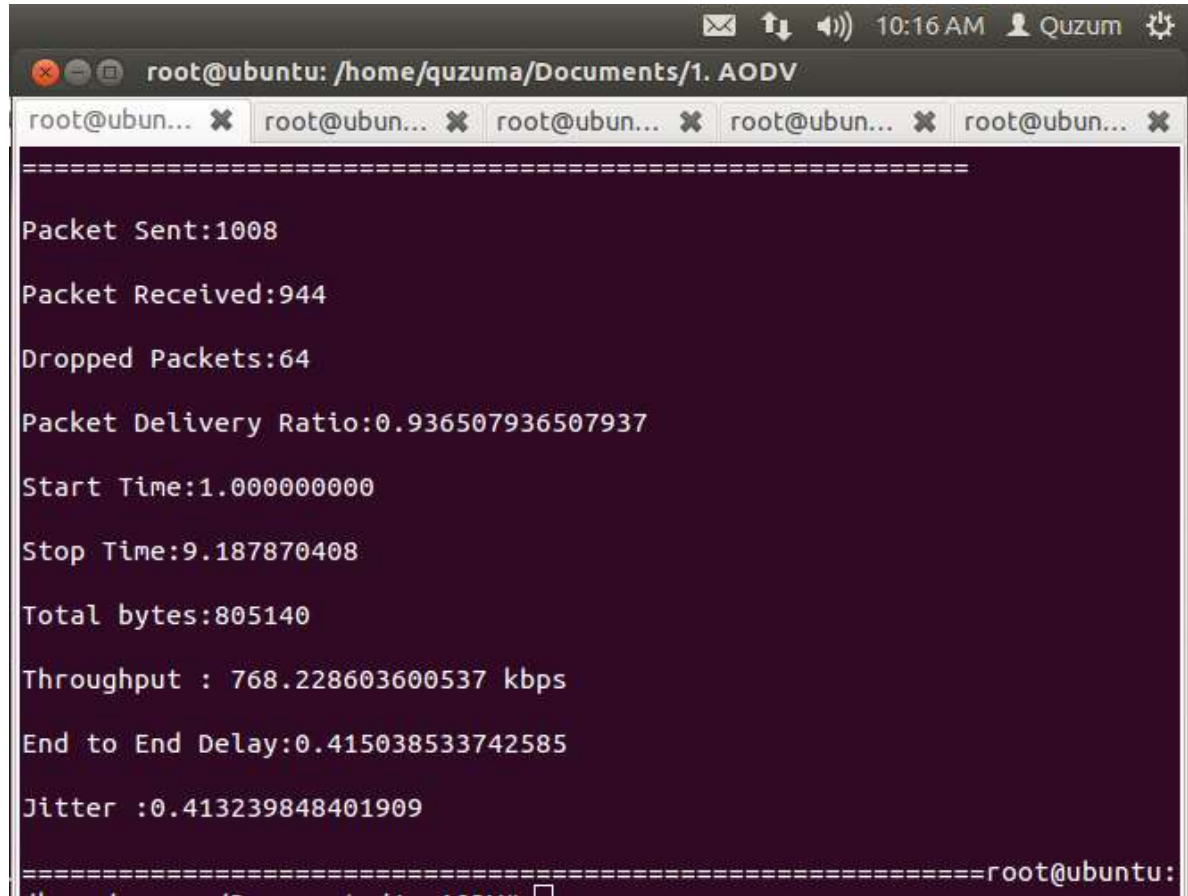

Gambar 9. Hasil Simulasi AODV 5 Node

\section{Kesimpulan}

\subsection{Kesimpulan}

Kesimpulan yang dapat diambil dari simulasi jaringan pada MANET pada routing protocol AODV dan ZRP menggunakan NS-2.33 adalah sebagai berikut:

1. Untuk membuat sebuah alur simulasi harus membuat script dengan file berekstensi *.tcl, dimana file berisi tentang penginisialisasian routing yang digunakan, jumlah paket yang dikirimkan, posisi node, jumlah node, dll. Dari hasil proses simulasi maka akan menghasilkan file dengan ekstensi ${ }^{*}$.tr dan *.nam, dimana file *.tr berisi tentang data hasil simulasi untuk 
mengetahui QoS dari simulasi tersebut sedangkan *.nam untuk animasi dari proses simulasi agar lebih mudah dipahami pergerakan dan pengiriman paket setiap node.

2. Hasil dari throughput yang lebih bagus dihasilkan dengan menggunakan routing protocol ZRP. Hal ini dikarenakan ZRP menganalisis node tujuan terlebih dahulu sehingga dalam pengiriman paket lebih baik. Dengan nilai rata-rata throughput pada ZRP adalah $963.34 \mathrm{~Kb}$ dibandingkan dengan AODV yang hanya $920.04 \mathrm{~Kb}$.

3. Delay paling sedikit terjadi pada routing protocol AODV dibandingkan dengan ZRP yang lebih cenderung memiliki delay lebih besar. Dengan menghasilkan nilai rata-rata sebesar 0.3134 dibandingkan dengan ZRP yang lebih besar yaitu 0.3891

4. Jitter dari masing-masing protocol dapat disimpulkan bahwa routing protocol ZRP memiliki nilai lebih tinggi dibandingkan dengan AODV. Dikarenakan AODV mengirimkan paket dengan node tujuan terdekat. Dengan nilai jitter dari AODV adalah 0.9026.

Berdasarkan rata-rata waktu routing dalam pengiriman paket dari masing-masing routing protocol, protocol AODV lebih cocok digunakan untuk jaringan yang memiliki jumlah 25 node, karena waktu dibutuhkan untuk membuat tabel routing lebih cepat dibandingkan dengan ZRP

\subsection{Saran}

Proses simulasi pada jaringan MANET yang menggunakan simulator NS-2.33 pada routing protocol AODV dan ZRP ini masih memiliki beberapa kekurangan yang dapat berguna untuk pengembangan selanjutnya, saran yang dapat diberikan antara lain:

1. Simulasi pada MANET ini tidak hanya terpaku pada AODV dan ZRP saja, namun bisa di dilakukan pada routing protocol lainnya.

2. Jumlah node dalam simulasi ini bisa dibuat lebih bervariasi dengan posisi node yang bervariasi juga untuk mendapatkan hasil yang lebih bagus lagi.

3. Pengembangan simulasi yang tidak hanya terpaku untuk MANET saja namun bisa untuk WANET, VANET, dsb.

Untuk hasil simulasi yang lebih bagus kedepannya variasi dalam keadaan jaringan antar node bisa ditambahkan seperti mobilitas jaringan yang lebih bervariasi.

\section{Referensi}

[1] E. H. Harahap, "Analisis Performansi Protokol AODV (Ad Hoc On Demand Distance Vector) dan DSR (Dynamic Source Routing) Terhadap Active Attack Pada MANET (Mobile Ad Hoc Network) Ditinjau dari Qos (Quality Of Service)," Tugas Akhir Universitas Telkom, Vol. 34, 2014.

[2] W. Desy, N, "Simulasi Kinerja Protokol Optimized Link State Routing (OLSR) dan Temporary Ordered Routing Algorithm (TORA) Pada Mobile Ad-Hoc Network Menggunakan OPNET," Tugas Akhir Politeknik Negeri Manado, 2016.

[3] H. E. Wahanani, J. T. Informatika, F. T. Industri, N. Disjoint, N. D. Path, "Kinerja Protokol Dsr Pada Jaringan Manet Dengan Metode Node Disjoint and Alternative Multipath," September, Pp. 33-41, 2013.

[4] F. Yoniko, "Analisa Perbandingan Kinerja Protokol OLSR Dan DSDV Pada Mobile Ad Hoc Network (MANET)" Tugas Akhir Universitas Muhammadiyah Malang., September, 2016

[5] N. Beijar, "Zone Routing Protocol (ZRP)," Netw. Lab. Helsinki Univ. Technol. Finl., Pp. 1-12, 2002.

[6] Z.J. Haas, M. R. Pearlman, P. Samer, "Intrazone Routing Protocol (IARP)," Internet Draft, 2001, available at:http://tools.ietf.org/id/draft-ietf-MANETs-iarp-01.txt

[7] Z.J. Haas, M. R. Pearlman, P. Samer, "The Bordercast Resolution Protocol (BRP)," Internet Draft, 2001, available at:http://tools.ietf.org/id/draft-ietf-MANETsbrp-01.txt

[8] Z.J. Haas, M. R. Pearlman, P. Samer, "Interzone Routing Protocol (IERP)," Internet Draft, 2001, available at:http://tools.ietf.org/id/draft-ietf-MANETs-ierp-01.txt

[9] Y. H. Arinatal, "Analisis Kecepatan Inisialisasi Jaringan Ad Hoc Pada Routing Protocol AODV, OLSR, dan ZRP Dengan NS 2," Tugas Akhir Universitas Sanata Dharma., Mei, 15 2015.

[10] S. Alicia, N. Xaverius, "Prototipe Aplikasi Sistem Informasi Akademik Pada Perangkat Android," Ejournal Unsrat, Vol. 2 No. 5, 2013

KINETIK Vol. 2, No. 3, Agustus 2017: 165-174 
